\title{
TO DETERMINE EFFICACY OF GRANISETRON VERSUS PLACEBO FOR REDUCING SHIVERING IN PATIENTS UNDERGOING LOWER SEGMENT CAESAREAN SECTION UNDER SPINAL ANAESTHESIA
}

\author{
Sana Abbas, Bilal Yasin, Basit Mehmood Khan, Umer Hayat, Rashid Hanif, Mohsin Fayyaz \\ Combined Military Hospital/National University of Medical Sciences (NUMS) Rawalpindi Pakistan
}

\begin{abstract}
Objective: To determine the efficacy of granisetron versus placebo (saline) for reducing shivering in patients undergoing lower segment caeserian section under spinal anaesthesia.

Study Design: Comparative cross - sectional study.

Place and Duration of Study: Department of Anaesthesia, Combined Military Hospital Rawalpindi, from Apr to Sep 2019.

Methodology: Total 178 patients undergoing lower segment ceaserian section under spinal anaesthesia with age ranges from 18-40 years of American Society of Anaesthesiologists status I \& II with full term pregnancy scheduled for elective caesarean section under spinal anaesthesia. Group A $(\mathrm{n}=92)$ received an intravenous bolus of $1 \mathrm{mg}$ granisetron in a 10ml syringe and Group B $(n=86)$ received intravenous bolus of normal saline in a $10 \mathrm{ml}$ syringe, drugs were administered immediately before spinal anaesthesia by anaesthetist as coded syringes. Heart rate, blood pressure, core body temperature and shivering scores were measured at 0 minutes, 30 minutes and 60 minutes, average surgery time recorded to be 60 minutes.

Results: None of the patients in group A (drug group) exhibited appreciable post spinal shivering whereas 25 (29\%) in group B (placebo) had clinically significant shivering necessitated administration of other established pharmacological agents to abort shivering in order to ensure patient comfort and satisfaction with statistically significant $p$-value of $<0.05$.

Conclusion: Prophylactic injection granisetron was efficacious against post spinal shivering, moreover provides worth while relief of nausea and vomiting which is dilemma with most of the drugs employed for control of post spinal shivering.
\end{abstract}

Keywords: Caesarean section, Granisetron, Post spinalanaesthesia.

This is an Open Access article distributed under the terms of the Creative Commons Attribution License (http://creativecommons.org/licenses/by/4.0), which permits unrestricted use, distribution, and reproduction in any medium, provided the original work is properly cited.

\section{INTRODUCTION}

Maintaining core body temperature during anaesthesia is a challenge for anaesthetist due to rapid heat loss, redistribution of body heat, effects of anaesthetic drugs and impairment of thermoregulation mechanisms by regional anaesthetic techniques. Shivering is an troublesome experience of the patient with undesirable physiologic phenomenon such as increased oxygen consumption, carbondioxide production, increased chances of myocardial ischemia, infection, bleeding, hypoxemia, lactic acidosis, increased intraocular pres-sure and intracranial pressure. Furthermore leads to misinterpretation of standard monitoring such as pulse oximetry, electrocardiography and noninvasive blood pressure thereby compromising patient management standards $\mathbf{s}^{1,2}$. Temperature regulating mechanism is divided into three constituents, thermosensors and afferent neuronal pathway, integration of thermal inputs and effector pathways for autonomic and behavioural regulation. Nucleus raphe magnus in the medulla oblongata contains high proportion of serotonergic neurons which is part of afferent neuronal pathway and

Correspondence: Dr Sana Abbas, Anaesthesia Department, Armed Forces Institute of Ophthalmology, Rawalpindi Pakistan

Received: 03 Dec 2019; revised received: 18 Jan 2020; accepted: 21 Jan 2020 integration of thermal inputs led to hypothesis of our research concept. Serotonin (5-Hydroxytryptamine; 5HT3), is a biological amine found in both brain and spinal cord as a major neurotransmitter. A sero-tonin 5-HT3 receptor antagonist inhibits reuptake of serotonin in the preoptic anterior hypothalamic region, which has impact on heat production and heat loss 3 . Granisetron is metabolized slowly by the liver, therefore have a longer average half life giving it advantage over odansetron, another 5-HT3 antagonist being trialed for prophylaxis of shivering after regional anaesthesia. Duration of action of granisetron is 4-9 hours eliminated by liver and kidneys. It is well tolerated drug with fewer side effects and drug interactions. It is free from sedative and extrapyramidal adverse effects ${ }^{4,5}$.

Sussan et al compared granisetron with saline for prevention of shivering after regional anaesthesia in parturient undergoing caesarian section under regional anaesthesia. They reported reduced frequency of post spinal shivering in granisetron group $(8 \%)$ versus the saline group (54\%); $p$-value $<0.05^{6}$.

Our research was based on fact that 5-HT3 receptor antagonists have significant role in preventing post spinal shivering on account of studies conducted on various drugs of this group $\mathrm{p}^{7-10}$. Our secondary objec- 
tive was to evaluate the efficacy in control of nausea and vomiting, in addition to determine any significant effects on parturient hemodynamic status and neonate by assessing neonatal APGAR score at $1 \mathrm{~min}$ and $5 \mathrm{~min}$ after birth.

\section{METHODOLOGY}

After approval of ethics review committee (1A/ 04/19) of the Combined Military Hospital Rawalpindi, consent was obtained after explaining the risks and benefits to the patients. This comparative cross - sectional study was conducted at department of Anaesthesia, Combined Military Hospital Rawalpindi, from Apr to Sep 2019.

The sample size was calculated by using WHO sample size calculator. The total sample size of study was 116, by keeping level of significance $95 \%$ confidence interva $1,5 \%$ error and anticipated (prevalence) frequency $8.15 \%$ was determined using 2016 study by Stone et all1 but we included 178 patients to further decrease chances of bias and increase authenticity of study. All patients undergoing lower segment ceaserian section under spinal anaesthesia with age ranges from 18-40 years of ASA I \& II status with full term pregnancyscheduled for elective caesarean section under regional anaesthesia, haemodynamically stable with no known co morbidswere recruited. Parturient having contraindication to regional anaesthesia, BMI> $35 \mathrm{~kg} / \mathrm{m}^{2}$, antepartum haemorrhage, pregnancy induced hypertension, preeclampsia, placenta previa, laboring patients were excluded from the study.

Patients were randomly allocated in two groups (group A and group B). As per study protocol, all the patients were interviewed, briefed, counseled about the procedure and informed written consent was taken. Before reporting to operation theatre, a detailed preanaesthesia assessment was carried out in all patients with necessary laboratory evaluation parameters in order to adhere with our inclusion and exclusion criteria, in addition ensure patient safety which is high priority of anaesthetic management.

On the day of surgery parturient were brought to operation theater and before initiating spinal anaesthesia standard monitoring such as pulse oximeter, non invasive blood pressure and electrocardiography via electrodes were attached and 18G IV cannula was passed under aseptic conditions. Parturient were preloaded with warm $\left(24-26^{\circ} \mathrm{C}\right) 1000 \mathrm{ml}$ of Ringer's Lactate. Operationg room temperature was maintained at $\left(24-26^{\circ} \mathrm{C}\right)$ with $60 \%$ humidity. Randomization protocol was followed for drug preparation and was administered by one of the anaesthetistin form of coded syringes. Group A received $1 \mathrm{mg}$ intravenous bolus of granisetron prepared in $10 \mathrm{ml}$ of $0.9 \%$ normal saline whereas group B received $10 \mathrm{ml}$ intravenous bolus of normal saline. Spinal anaesthesia was performed on patient in sitting position at L3-L4 or L4-L5 interspace after sterilization and drape, $25 \mathrm{G}$ Quincke and Pencil Point needle was used, 8-10 $\mathrm{mg}$ of $0.5 \%$ hyperbaric bupivacaine was injected over a minute followed by positioning patient supine and placing wedge under right hip to ensure left uterine displacement. T4 sensory level block was confirmed with ethyl chloride spary and motor block was confirmed with bromage scale $(0=$ no block, $1=$ hip block, $2=$ hip and knee block, 3=hip, knee and ankle block). Patient's hemodynamic status and tympanic membrane temperature with infrared tympanic thermometer was measured at 0 minute, 30 minutes and 60 minutes. $0 \mathrm{~min}$ was considered at point of drug administration and average surgery time documented was 60 minutes. Patient shivering score was assessed by using validated five point scale (table-I) ${ }^{12}$.

APGAR score (table-II) was measured at 1 minute and 5 minutes after birth which remained between 7-10 which is considered essentially normal ${ }^{13}$.

Table-I: Patient shivering score.

\begin{tabular}{l|l}
\hline Score & Definition \\
\hline 0 & No shivering \\
\hline 1 & $\begin{array}{l}\text { Piloerection or peripheral vasoconstriction but } \\
\text { no visible shivering }\end{array}$ \\
\hline 2 & Muscular activity in only one muscle group \\
\hline 3 & $\begin{array}{l}\text { Muscular activity in more than one muscle } \\
\text { group but not generalized }\end{array}$ \\
\hline 4 & Shivering involving the whole body \\
\hline
\end{tabular}

\begin{tabular}{l|c|c|c}
\hline Table-II: Neonatal APGAR Score. & $\mathbf{1}$ & $\mathbf{2}$ \\
\hline Sign & $\mathbf{0}$ & $\begin{array}{c}\mathbf{1} \\
\text { Heart Rate } \\
\text { Heats }\end{array}$ & $\begin{array}{c}>100 \text { beats } \\
/ \text { min }\end{array}$ \\
\hline $\begin{array}{l}\text { Respiratory } \\
\text { Effort }\end{array}$ & Absent & $\begin{array}{c}\text { Slow, } \\
\text { Irregular }\end{array}$ & $\begin{array}{c}\text { Good, } \\
\text { Crying }\end{array}$ \\
\hline $\begin{array}{l}\text { Muscle } \\
\text { Tone }\end{array}$ & Limp & $\begin{array}{c}\text { Some Flexion of } \\
\text { Extremities }\end{array}$ & $\begin{array}{c}\text { Active } \\
\text { Motion }\end{array}$ \\
\hline $\begin{array}{l}\text { Reflex } \\
\text { Irritability }\end{array}$ & $\begin{array}{c}\text { No } \\
\text { Response }\end{array}$ & Grimace & $\begin{array}{c}\text { Cough, Sneeze, } \\
\text { or Cry }\end{array}$ \\
\hline Color & $\begin{array}{c}\text { Pale, } \\
\text { Blue }\end{array}$ & $\begin{array}{c}\text { Body Pink, } \\
\text { Extremities blue }\end{array}$ & $\begin{array}{c}\text { Completely } \\
\text { Pink }\end{array}$ \\
\hline
\end{tabular}

Data was analysed by using SPSS-23. Frequency and percentage were calculated for qualitative data. Mean \pm SD was calculated for continuous variables. Independent sample t-test and chi square test were 
applied for comparison of group A and group B as required. A $p$-value $\leq 0.05$ was considered as significant.

\section{RESULTS}

A total of 178 females were included of ASA status I \& II (table-IV), mean age of patients was 28.76 \pm 4.67 years range from $18-40$ years. Data was divided in to two groups group A (drug group) and group B (Placebo), $92(51.7 \%)$ patients was in group A and 86 minutes of group A was $0.13 \pm 0.03$ and in group B was $0.94 \pm 0.62(p=0.001)$, mean of shivering score at 60 minutes of group A was $0.2 \pm 0.14$ and in group B was $1.31 \pm 1.21(p=0.001)$. Shivering score was higher in group $B$ and was statically significant as depicted in (table-III \& fig-1). $29.06 \%(n=25)$ patients in Group B were given Inj Tramadol Hydrochloride in order to relieve significant shivering whereas none of the parturient augmented with any other pharmacological the-

Table-III: Comparison of monitored parameters among group A (Granisetron) \& group B (Placebo).

\begin{tabular}{|c|c|c|c|}
\hline & Group A (n=92) & Group B $(n=86)$ & $p$-value \\
\hline Age & $28.77 \pm 4.50$ & $28.74 \pm 4.88$ & 0.969 \\
\hline Time duration & $61.63 \pm 5.88$ & $62.21 \pm 5.17$ & 0.488 \\
\hline Heart Rateat 0 minute & $106.87 \pm 20.166$ & $99.77 \pm 14.515$ & 0.007 \\
\hline Heart Rate at 30 minutes & $95.43 \pm 13.937$ & $95.62 \pm 13.046$ & 0.929 \\
\hline Heart Rate at 60 minutes & $87.48 \pm 9.383$ & $91.21 \pm 14.34$ & 0.04 \\
\hline Tympanic membrane temperature at 0 minute & $37.724 \pm 0.36$ & $37.845 \pm 0.464$ & 0.051 \\
\hline Tympanic membrane temperature at 30 minutes & $37.778 \pm 0.47$ & $37.524 \pm 0.56$ & 0.001 \\
\hline Tympanic membrane temperature at 60 minutes & $37.546 \pm 0.49$ & $37.524 \pm 0.56$ & 0.001 \\
\hline Shivering score at 0 minute & $0.91 \pm 0.58$ & $0.71 \pm 0.65$ & 0.029 \\
\hline Shivering score at 30 minutes & $0.13 \pm 0.03$ & $0.94 \pm 0.62$ & 0.001 \\
\hline Shivering score at 60 minutes & $0.2 \pm 0.14$ & $1.31 \pm 1.21$ & 0.001 \\
\hline Systolic BP at 0 minute & $128.33 \pm 15.93$ & $129.08 \pm 12.48$ & 0.726 \\
\hline Diastolic BP at 0 minute & $78.08 \pm 13.11$ & $77.24 \pm 10.18$ & 0.634 \\
\hline Systolic BP at 30 minutes & $113 \pm 14.20$ & $118.26 \pm 13.94$ & 0.013 \\
\hline Diastolic BP at 30 minutes & $65 \pm 12.06$ & $69.06 \pm 9.84$ & 0.015 \\
\hline Systolic BP at 60 minutes & $110.15 \pm 13.47$ & $112.67 \pm 8.5$ & 0.140 \\
\hline Diastolic BP at 60 minutes & $62.94 \pm 12.71$ & $64.26 \pm 5.84$ & 0.379 \\
\hline
\end{tabular}

$(48.3 \%)$ in group B). Mean age of group A was $28.77 \pm$ 4.50 and group B was $28.74 \pm 4.88(p=0.969)$. Mean time duration was $61.91 \pm 5.55$ minutes in group $A$ and in group B was $62.21 \pm 5.17$ minutes $(p=0.488)$. Mean heart rate at 0 minute was $103.44 \pm 17.97$, in group A was $106.87 \pm 20.166$ and in group B was $99.77 \pm 14.515$ $(p=0.007)$. Mean of heart rate at 30 minutes was $95.52 \pm$ 13.47, in group A was $95.43 \pm 13.937$ and group B was $95.62 \pm 13.046(p=0.929)$. Mean of heart rate at 60 minutes was $89.28 \pm 12.14$, mean of group A was 87.48 \pm 9.383 and in group B was $91.21 \pm 14.34(p=0.04)$. Mean tympanic membrane temperature at 0 minutes, 30 minutes and 60 minutes was $37.783 \pm 0.41,37.65$ \pm 0.53 and $37.40 \pm 0.55$ respectively. In group $A$ the mean tympanic membrane temperature at 0 minutes, 30 minutes and 60 minutes was $37.724 \pm 0.36,37.778$ \pm 0.47 and $37.546 \pm 0.49$ respectively and in group B mean of tympanic membrane temp at 0 minutes, 30 minutes and 60 minutes was $37.845 \pm 0.464,37.524 \pm$ $0.56,37.524 \pm 0.56$ and there $p$-values were $0.051,0.001$ and 0.001 respectively. Mean of shivering score at 0 minute of group A was $0.91 \pm 0.58$ and group B was $0.71 \pm 0.65(p=0.029)$, mean of shivering score at 30 rapy for shivering prophylaxis. Systolic and diastolic blood pressure was higher in group B at 30 minutes interpreting a signficant statistical difference.

(Table-III \& fig-1) Incidence of nausea and vomiting recorded to be $9(10.46 \%)$ in group B requiring emesis mangement.

Table IV: Distribution of patients according to ASA status ( $\mathrm{n}=\mathbf{1 7 8 )}$.

\begin{tabular}{l|c|c|c}
\hline \multirow{2}{*}{ ASA } & $\begin{array}{c}\text { Group A } \\
(\mathbf{n = 9 2 )}\end{array}$ & $\begin{array}{c}\text { Group B } \\
(\mathbf{n = 8 6 )}\end{array}$ & Total (n=178) \\
\cline { 2 - 4 } & $\mathbf{n ~ ( \% )}$ & $\mathbf{n ~ ( \% )}$ & $\mathbf{n}(\mathbf{0})$ \\
\hline $\mathrm{I}$ & $72(78.3)$ & $72(83.7)$ & $144(80.89)$ \\
\hline II & $20(21.7)$ & $14(16.3)$ & $34(19.10)$ \\
\hline
\end{tabular}

\section{DISCUSSION}

Data analysis of research interpreted statistically significant efficacy of granisetron in management of shivering encountered after commencement of regional anaesthesia, moreover provided an added benefit of prevention from nausea and vomiting was achieved. There was no incidence of shivering in granisetron group however $25(29 \%)$ patients in placebo (normal saline) group required administration of $50 \mathrm{mg}$ intra- 
venous bolus of tramadol hydrochloride for effective control of shivering and $9(10.4 \%)$ patients presented with complaint of nausea and vomiting which was treated with $10 \mathrm{mg}$ intravenous bolus of metoclopramide ${ }^{14,15}$.

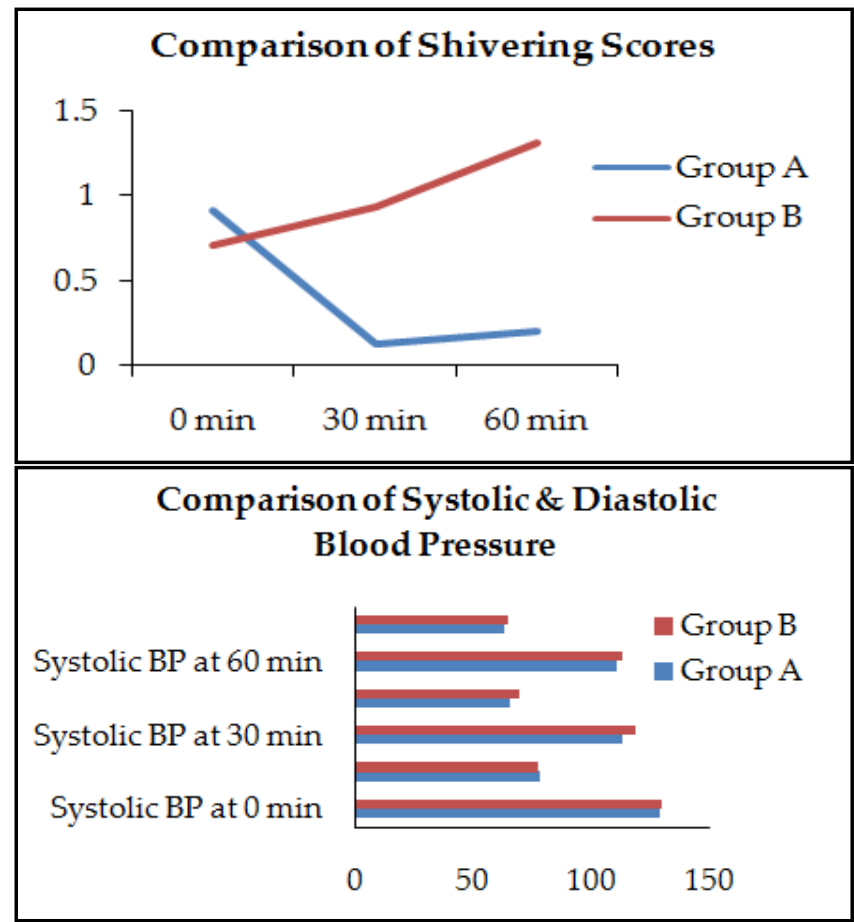

Figure: Trends of shivering scores \& blood pressure in group A $(n=92)$ and group $B(n=86)$.

Zhou et al conducted a meta - analysis that included 14 randomized controlled trials that demonstrated significant efficacy of 5-HT3 receptor antagonists in control of shivering after regional anaesthesia in comparison to placebo $^{16}$. Moreover potency was comparable to meperidine with added advantage of prevention of nausea, vomiting and lack of respiratory depression which is a major concern with meperidine administration ${ }^{17}$. Sajedi et al illustrated that granisetron is as beneficial as tramadol hydrochloride in preventing post operative shivering in patients undergoing elective orthopedic surgery under general anaesthesia but tramadol has troublesome effects of nausea, vomiting and dizziness resultantly lead to less patient satisfaction and delay in early ambulation ${ }^{18}$.

Sagir et al compared prophylactic ketamine and granisetron for control of shivering during regional anaesthesia but hallucinations associated with ketamine limits its use in parturient ${ }^{19}$. Aldaba and Amir in there study demonstrated that $1 \mathrm{mg}$ intravenous bolus of granisetron attenuated decrease in systolic and diastolic blood pressure which is evident after spinal block, these findings are consistent with our study as systolic and diastolic blood pressure was higher in group B at 30 minutes of analysis and difference was statistically significant ${ }^{20}$.

Therefore, peculiar thing about our research project was that a single agent is cure for nausea, vomiting and shivering after regional anaesthesia all of which are concerns for an anaesthetist in parturient management and satisfaction undergoing caesarean section under regional anaesthesia.

\section{LIMITATION OF STUDY}

Our study had limitation that it was not multicentred as procurement of drug was difficult due to cost and limited availability. Moreover shivering grade was assessed subjectively on basis of shivering grades only which could have led to inaccurate human perception.

\section{ACKNOWLEDGEMENT}

Authors are obliged to the seniors, colleagues, staff of the operating theatre \& for assistance in data collection and smooth conduction of research.

\section{CONCLUSION}

Prophylactic administration of granisetron $1 \mathrm{mg}$ intravenously effectively prevents shivering in parturient undergoing lower segment caesarean section, furthermore provides beneficial relief of nausea and vomiting which is dilemma with most of the drugs employed for control of post spinal shivering and parturient undergoing caesarean section. Another advantage of granisetron is availability of sustained release formulations in form of FDA approved transdermal patches which can provide relief from metabolic over burden due shivering manifested after regional anaesthesia, nausea and vomiting for longer period post operatively.

\section{CONFLICT OF INTEREST}

This study has no conflict of interest to be declared by any author.

\section{REFERENCES}

1. Kabade DS, Venkatesh, Karthik, Kumar. Comparative study of granisetron versus pethidine for the prevention of perioperative shivering under spinal Anesthesia. Karnataka Anesthesia J 2016; 2(1): 14-18.

2. Sun J, Zheng Z, Li Y, Zou L, Li G, Wang X, et al. Nalbuphine versus dexmedetomidine for treatment of combined spinalepidural post-anesthetic shivering in pregnant women undergoing cesarean section. J Intl Med Res 2019; 47(9): 4442-53.

3. Block M, Sinner B, Gottlicher M, Simon E, Martin E, Motsch J. Involvement of serotonergic pathways in postanesthetic cold 
defence: Dolasetron prevent shivering. J Thermal Biol 2002; 27(2): 159-66

4. Abdel-Ghaffar HS, Moeen SM. Prophylactic granisetron for postspinal anesthesia shivering in cesarean section: A randomized controlled clinical study. Acta Anaesthesiol Scand 2018; 63(3): 381-88.

5. Joshi SS, Atora A, George. Comparison of Intravenous butarphanol, odansetron and tramadol for shivering during regional anaesthesia: A propspective randomized double - blind study. Anaesth Pain Inten Care 2013; 17(1): 33-39.

6. Mohammadi SS, Jabbarzadeh, Movafegh. Efficacy of granisetron on prevention of shivering, nausea and vomiting during cesarean delivery under spinal anesthesia: A randomized doubleblinded clinical trial. J Obs Anaesth Crit Care 2015; 5(1): 22-26.

7. Varshney KR, Garg, Kapoor, Jheetay S. The role of ramosetron in the prevention of post-spinal shivering in obstetric patients. A prospective randomized double blind study. Romanian J Anaesth Inten Care 2019; 26(1): 37-43.

8. Kim MS, Kim DW, Woo SH, Yon JH, Lee S. Effect of ramosetron on shivering during spinal anaesthesia. Korean J Anesthesiol 2010; 58(3): 256-59.

9. Nallam SR, Cherukuru K, Sateesh G. Efficacy of intravenous ondansetron for prevention of post-spinal shivering during lower segment cesarean section: a double-blinded randomized trial. Anesth Essays Res 2017; 11(2): 508-13.

10. Shin HJ, Choi ES, Lee GW, DO SH. Effects of preoperative serotonin-receptor-antagonist administration in spinal anesthesiainduced hypotension: a randomized, double-blind comparison study of ramosetronand ondansetron. Reg Anesth Pain Med 2015; 40(5): 583-88.

11. Luggya ST, Kabuye NR, Mijumbi C, Tindimwebwa BJ, Kintu A.
(2016) Prevalence, associated factors and treatment of post spinal shivering in a Sub-Saharan tertiary hospital: a prospective observational study. BMC Anesthesiol 2016; 16(1): 100.

12. Jain A, Gray, Slisz, Haymore, Badjatia, Kulstad. Shivering treatments for targeted temperature management: a review. J Neuro Sci Nurs 2017; 50(2): 63-67.

13. Kliegman MR. Nelson Textbook of Pediatrics. $20^{\text {th }}$ ed. Philadelphia: Elsevier 2016; (94): 794-98.

14. Mishriky MB, Habib S. Metoclopramide for nausea and vomiting prophylaxis during and after Caesarean delivery: a systematic review and meta-analysis. Br J Anaesth 2012; 108(3): 374-83.

15. Vyas V, Gupta R, Dubey P. Comparative efficacy and safety of intravenous clonidine and tramadol for control of postspinal anesthesia shivering. Anesth Essays Res 2018; 12(3): 663-68.

16. Zhou C, Zhu Y, Bao Z, Wang X, Liu Q. Efficacy of ondansetron for spinal anesthesia during cesarean section: a meta-analysis of randomized trials. J Int Med Res 2018; 46(2): 654-62.

17. Jayaraj A, Balachander, Kuppusamy K, Arusamy Rai, Siddiqui. Comparison of meperidine, tramadol and fentanyl for postspinal shivering prevention during cesarean delivery: A doubleblind randomized controlled trial. J Obs Gyna Res 2019; 45(11): 2202-08.

18. Sajedi P, Moseli A, Efficacy of Granisetron in Preventing Post anesthetic Shivering. Acta Anaesth Taiwanica 2008; 46(4): 166-70.

19. Sagir O, Gulhas, Toprak, Yucel. Control of shive-ring during regional anaesthesia: prophylactic ketamine and granisetron. Acta Anaesthesiologica Scandinavica, 2006; 51(1): 44-49.

20. Aldaba AA, Amir MY. Intravenous granisetron attenuates hypotension during spinal anesthesia in cesarean delivery: A doubleblind, prospective randomized controlled study. J Anaesthesiol Clin Pharmacol 2015; 31(3): 329-32. 